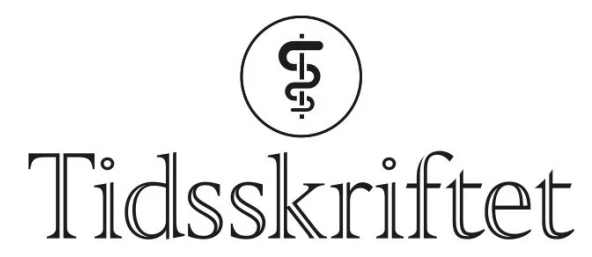

DEN NORSKE LEGEFORENING

\title{
Ny standard for EEG-beskrivelse
}

\author{
NYHETER
}

\section{HARALD AURLIEN}

Email: harald.aurlien@helse-bergen.no

Haukeland universitetssykehus

\section{Norske leger og teknologer har vært sentrale i utviklingen av en ny standard for beskrivelse av EEG.}

Som ved de fleste medisinske prosedyrer beskrives resultatet av EEG-unders $\varnothing$ kelser som oftest i fritekst, som lagres i pasientens journal. Dette gir rom for stor variasjon mellom ulike EEG-tolkere. Resultatene blir ikke søkbare og ikke tilgjengelige for statistiske analyser. Vår målsetting var å lage et dataprogram for EEG-tolking hvor man skulle benytte internasjonalt anerkjent terminologi og samtidig lagre funnene i en søkbar database. EEGeksperter fra 14 europeiske land har deltatt i utarbeidingen av terminologien og testing av programvaren, som har resultert i et nytt skåringssystem kalt SCORE (Standardized Computer-based Organized Reporting of EEG). Arbeidet har vært organisert med støtte fra det europeiske avsnittet av organisasjonene International League Against Epilepsy (ILAE) og International Federation of Clinical Neurophysiology (IFCN), og resultatet er nylig publisert i tidsskriftet Epilepsia (1).

De norske nevrofysiologene Harald Aurlien og Jan Brøgger har sammen med teknologer i Holberg EEG AS ved Haukeland universitetssykehus utviklet SCORE-programvaren, som allerede er oversatt til flere språk. Den lagrede informasjonen i databasen er imidlertid uavhengig av hvilket språk som brukes for beskrivelse. Dette betyr at resultater av EEGundersøkelser nå kan sammenliknes direkte på tvers av ulike språk og tradisjoner. En gratis versjon av programvaren kan lastes ned fra www.holbergeeg.com/.

\footnotetext{
LITTERATUR

1. Beniczky S, Aurlien H, Brøgger JC et al. Standardized Computer-based Organized Reporting of EEG: SCORE. Epilepsia 2013; 54: 1112-24. [PubMed] [CrossRef]
}

Publisert:3. september 2013. Tidsskr Nor Legeforen. DOI: 10.4045/tidsskr.13.0850 (C) Tidsskrift for Den norske legeforening 2023. Lastet ned fra tidsskriftet.no 26. april 2023. 